\title{
Local 1's Unionism and the Transformation of Iowa's Politics, 1939-1970
}

\author{
WILSON J. WARREN
}

The following article is reprinted with permission from Struggling with "Iowa's Pride": Labor Relations, Unionism, and Politics in the Rural Midwest since 1877, by Wilson J. Warren (University of Iowa Press, 2000). It is reprinted here because it aptly complements the other two articles in this issue, expanding and providing context for their narratives.

Previous chapters in the book recounted the emergence and erosion of a militant unionism in Local 1 of the United Packinghouse Workers of America, which represented workers at the John Morrell and Company meatpacking plant in Ottumwa. - Editor

LOCAL 1'S MILITANT UNIONISM keyed Iowa's political transformation in the post-World War II years. Morrell workers' $\mathrm{CIO}$ movement quickly moved beyond plant organizing and bargaining with the company into a larger political struggle for greater power in city and state politics. Ottumwa's meatpacking workers, together with other blue-collar workers and middleclass residents of the city, became Democratic supporters who precipitated a remarkable transition in partisan politics in Ottumwa, Wapello County, and Iowa as a whole. Indeed, Ottumwa's $\mathrm{CIO}$ movement, combined with meatpacking, auto-worker, and farm equipment worker unionism across the state, helped to

THE ANNALS OF IOWA 76 (Winter 2017). @ State Historical Society of Iowa, 2017. 
transform Iowa's political landscape from solid Republicanism to competitive two-party status. ${ }^{1}$

This Democratic transition started in the 1930s but did not culminate until the 1960s. As historian James L. Sundquist describes in Dynamics of the Party System, the Democratic ascendancy in Iowa and fifteen other northern states was part of a two-stage realignment that spanned the 1930s to the 1950s. Developments among packing workers in Ottumwa illustrate these findings quite well. The packing community's enthusiasm for unionism in the 1930s did not immediately carry over into support for the Democratic party. From the 1860 presidential election until 1928, Ottumwa and Wapello County were usually dependable Republican strongholds in local, state, and national politics, not unlike most of Iowa's cities and counties. Only during the late nineteenth century and then during World War I had Democrats enjoyed success in Ottumwa and Wapello County. Unlike the situation in other industrial cities elsewhere, the 1928 presidential election results did not presage later Democratic landslides; Hoover drubbed Smith in the packing district's Ward One by a 60 to 40 percent margin. Beginning with the 1932 presidential election, however, Iowa Democrats in both urban and rural areas won by landslide margins in the 1932, 1934, and 1936 national and state elections. As in so many midwestern states, though, Democratic gains largely reflected farmers' protest voting. By 1938, with the New Deal agricultural programs addressing farm problems, Democratic gains declined throughout most of Iowa, even in the industrial cities. Although the Democrats received majorities in

1. The standard argument, expressed especially by Harlan Hahn, is that Iowa's Democratic transition rested with both its farmers and urban residents (defined as cities with over 10,000 population). Hahn attributes the support for Democratic candidates among urban residents owing mainly to issues of taxation, liquor control, and legislative reapportionment. Neither he nor James Larew, though the latter is more generous in crediting labor's assistance, focus centrally on the contribution of Iowa's growing labor union movement to the Democratic tradition. Shelton Stromquist's synthesis of oral histories on Iowa's labor movement suggests this connection, but it is not systematically examined. See Harlan Hahn, Urban-Rural Conflict: The Politics of Change (Beverly Hills, CA, 1971); James C. Larew, A Party Reborn: The Democrats of Iowa, 1950-1974 (Iowa City, 1980); Shelton Stromquist, Solidarity and Survival: An Oral History of Labor in the Twentieth Century (Iowa City, 1993), 282-94; and Dorothy Schwieder, Iowa: The Middle Land (Ames, IA, 1996), 290-91. 
Ottumwa and Wapello County during the early 1930s, the packing community did not turn out for Roosevelt to a much greater degree than the rest of the city's voters. ${ }^{2}$

With the 1936 election, though, Ottumwa's industrial workers' selections foretold the significant swing to the Democratic ticket by voters in industrial communities in the state after World War II. Between 1944 and 1972, the original packing district and the south side precincts (where even larger numbers of Morrell workers lived after World War II, and who were joined by workers at the UAW-affiliated Deere plant) averaged 65 and 60 percent majorities, respectively, for Democratic presidential candidates. Even more significant, the residents of Ottumwa and Wapello County as a whole voted solidly Democratic for not only presidential candidates but congressional and state-level politicians as well. From 1932 to 1948, Democrats won 52 percent of Wapello County and Ottumwa's gubernatorial vote. Between 1950 and 1972, Democrats garnered 58 percent of the total vote in Wapello County, and 59 percent of the vote in Ottumwa during the same period. From the Civil War to 1954, only two Democrats had occupied the governor's office in Iowa, Horace Boies in 1889 and 1891 and Clyde Herring in 1932 and 1934. With voters in Ottumwa and Wapello County leading the way and contributing to concerted urban support across the state, Democrats Herschel Loveless, an Ottumwa native with working-class roots, and former trucker Harold Hughes won the governor's seat five times between 1956 and 1966. ${ }^{3}$

Accompanying the transformation of voting behavior was the direct political participation of workers from Morrell and

2. James L. Sundquist, Dynamics of the Party System: Alignment and Realignment of Political Parties in the United States, rev. ed. (Washington, DC, 1983), 256-57; Larew, A Party Reborn, 7; State of Iowa, Official Register, 1933-1934 (Des Moines, 1933); and State of Iowa, Official Register, 1941-1942 (Des Moines, 1942). Regarding the designation of Ottumwa's Ward One, beginning in the 1932 election, Ward One was reconstituted as Precincts One and Two. I have generally retained use of the designation First Ward (or Ward One) for the sake of continuity with earlier chapters. Although part of the two-stage realignment, Iowa obviously still lagged behind the political revolution wrought by the Democrats in much of the rest of the urban Midwest and Northeast as early as the 1920s. See Richard Oestreicher, "Urban Working-Class Political Behavior and Theories of American Electoral Politics, 1870-1940," Journal of American History 74 (March 1988), 1257-86.

3. State of Iowa, Official Registers, 1933-34 through 1973-74. 
other industries in Ottumwa in city and state politics. From the 1940s to mid-1950s several union members ran for various city, county, and state offices, and assumed leading roles in the unionorganizing campaigns of other plants around the region. Union representatives from Ottumwa were especially instrumental in the union drive at the Rath Packing Company plant in Waterloo, a somewhat larger manufacturing city in northeast Iowa. Home to Iowa's two largest factories, Rath and John Deere, both CIO organized, Waterloo would emerge in the late 1940s and early 1950 s as the other leading CIO locale in the state. Constituting the largest bloc of union members in the state's CIO council, Waterloo and Ottumwa representatives, working together with other representatives from the state's packinghouse and auto worker unions, would promote the political action programs that would transform Iowa's Republican-dominated political establishment into a much more balanced two-party system by the 1960s.

The transformation of voting behavior and workers' direct political participation were mutually reinforcing in Ottumwa through the 1950s. Union leaders, motivated by the same desire for power and control that had sparked most of their union objectives in the plant in the 1930s and 1940s, also ran for political offices to gain a more direct role in community affairs. For union leaders, achieving greater influence in the community was just as important as it was in plant affairs. Their concerns were also increasingly expressed in the voting behavior of rank-and-file unionists as well as significant segments of Ottumwa's population as a whole. As local union achievements became increasingly linked to those of other unions in the industry and around the Midwest by the mid-1940s, Morrell-Ottumwa workers' political horizons became likewise broader. From the mid-1940s to the early 1950s, as workers battled with Morrell's management for control in key production decisions, they also struggled for power in local and state political arenas.

Local 1 was at the forefront of Iowa's Democratic transition long before the post-World War II years. Beginning in 1940, union members registered large numbers of new voters in Wapello County. Then in fall elections of that year, Ottumwa gave Roosevelt his largest percentage victory among all Iowa's industrial 
cities. ${ }^{4}$ With the organization of the CIO's political action committee (PAC) in 1944, workers participated significantly in local Democratic party campaigns. From 1946 through the 1960s, Ottumwa workers' central role in shaping the Iowa-Nebraska States, later Iowa State, Industrial Union Council's CIO-PAC efforts and then the merged AFL-CIO Iowa State Federation of Labor's state-level political efforts resulted not only in consistent Democratic victories in local and county politics, but also helped to secure Democratic successes at the state and national level by the 1960s.

\section{Building a "Union Politic" in Ottumwa}

In 1885, Republican orator, later U.S. senator, Jonathan P. Dolliver claimed that "Iowa will go Democratic when Hell goes Methodist." In fact, Republicans did not dominate Iowa's politics until after the turn of the twentieth century. For much of the late nineteenth century, struggles among the various groups that had settled the state, including Yankees, upland southerners, and foreigners, particularly Germans, over racial equality and Prohibition made Democrats and Republicans fairly evenly matched. Ottumwa generally reflected the state's diverse ethnocultural mix and political heritage from the mid-nineteenth century through the 1920s. Although populated by some Irish and German Catholic immigrants, Ottumwa's Democratic supporters in the late nineteenth century were often American-born with roots in the South, unlike Dubuque, where Irish and German Catholics turned that city into a major center of Democratic party support. Situated in the southern half of Iowa where upland southerners were among the earliest settlers, from its earliest years Ottumwa's working class demonstrated a noticeable tendency to vote more Democratic than the city as a whole. In the 1856 presidential election, Wapello County, like several of the counties in the two southernmost tiers of the state, returned majorities for the Democratic candidate, James Buchanan. ${ }^{5}$

4. Among Iowa's industrial cities in 1940, Roosevelt won 58 percent of the vote in Ottumwa, followed by Fort Dodge with 56 percent, Davenport, Mason City, and Sioux City each with 54 percent, Waterloo with 52 percent, Dubuque and Des Moines with 49 percent. See State of Iowa, Official Register, 1941-42.

5. Dolliver quoted in Hahn, Urban-Rural Conflict, 17. On the cultural streams of Iowa settlers, see Hahn, Urban-Rural Conflict, 35-36; Nicole Etcheson, The Emerging 
Yet beginning with the 1860 presidential election through 1928, the majority of Ottumwa and Wapello County voters, like Iowa's voters in general, normally turned out for the Grand Old Party. Although Ottumwa's working-class voters, particularly those in the Ward One packing district, did vote more strongly for Democrats between 1888 and 1936, the difference between their turnouts compared to those for the rest of the city's voters was generally only a few percentage points. Ottumwa and Wapello County voters also demonstrated a somewhat higher proclivity to vote for third-party candidates, especially Socialists and Progressives though not Populists, resulting in somewhat lower percentage returns for Republicans than the state as a whole, but otherwise there was little significant difference between Ottumwa, Wapello County, and Iowa in Democratic voting tendencies during this period. The Republican party's dominance in Wapello County before the 1930s is also evident when looking at county elected officials. Between 1898 and 1932, only during the period from 1906 to 1912 were there more Democratic officials than Republicans in Wapello County. ${ }^{6}$

Midwest: Upland Southerners and the Political Culture of the Old Northwest, 17871861 (Bloomington, IN, 1996), 2, 109-27; Morton M. Rosenberg, Iowa on the Eve of the Civil War: A Decade of Frontier Politics (Norman, OK, 1972), 18-23; John C. Hudson, Making the Corn Belt: A Geographical History of Middle-Western Agriculture (Bloomington, IN, 1994); Jon Gjerde, The Minds of the West: Ethnocultural Evolution in the Rural Middle West, 1830-1917 (Chapel Hill, 1997), 4-5; and Robert R. Dykstra, Bright Radical Star: Black Freedom and White Supremacy on the Hawkeye Frontier (Cambridge, MA, 1993), vii. On Iowa's politics in the late nineteenth century, see Schwieder, Iowa, 31-32, 72-73, 76-77, 211-29; Larew, A Party Reborn, 1-9; Dykstra, Bright Radical Star, 58, 63, 108, 120-23, 250-54, 261; and Jeffrey Ostler, Prairie Populism: The Fate of Agrarian Radicalism in Kansas, Nebraska, and Iowa, 1880-1892 (Lawrence, KS, 1993), 37-53, 138-42. On Wapello County's nineteenth-century demographics and politics, see Dykstra, Bright Radical Star, 145; Mildred Throne, "A Population Study of an Iowa County in 1850," Iowa Journal of History (October 1959), 314-18; and 1895 Iowa Census Manusript.

6. Voting data on Ottumwa and Wapello County were obtained from State of Iowa, Official Registers, 1890 to 1931-32. The two exceptions to Ward One's slightly higher level of Democratic support compared to the rest of the city in this period occurred in 1916 and 1926. Ward One's voters cast a higher percentage for the Republican gubernatorial candidate, William Harding, in 1916 because of his anti-Prohibition campaign. In 1926, Republican Smith W. Brookhart, a progressive Republican, captured 60 percent of the First Ward's votes compared to just 48 percent for Ottumwa. Brookhart campaigned particularly on behalf of economic relief for Iowa's hard-pressed farmers. This economic focus reflected Brookhart's conscious rejection of the older state political focus on prohibition 
The real watershed in the packing district's voting behavior occurred with the 1936 presidential election. Although the packing district gave 56 percent to Roosevelt in 1932, Wapello County as a whole actually supported Roosevelt at an even higher rate of 57 percent. Indeed, the 1932 and 1934 gubernatorial and 1932 U.S. Senate races demonstrated the same pattern. These results lend credence to Harlan Hahn's argument that Roosevelt's success in Iowa's 1932 presidential election was largely owing to rural protest votes. Across Iowa in 1932, farmers gave Roosevelt 70 percent of their vote compared to just over 50 percent from residents of towns over 10,000. The returns from the packing district from 1936 on, however, were consistently higher for Democrats and markedly greater than that of the entire city or county, though the returns from these larger areas also showed consistently higher returns for Democrats. ${ }^{7}$

The underpinning of this Democratic transition in Ottumwa was the extension of workers' struggles for greater power and control in the Morrell plant to the city as a whole. The 1939 strike and the shop-floor struggles that were endemic in the plant in the

and ethnocultural issues. It may be that Morrell workers looked to Brookhart, who would remain a Republican but was "a New Dealer before [there was] a New Deal," more because of this economic focus, an area of concern that certainly would appeal to them during and after the New Deal, than its traditional concerns with Prohibition. On the 1916 gubernatorial race in Iowa, see Edward Franklin Cox, State and National Voting in Federal Elections, 1910-1970 (Hamden, CT, 1972); and John Thomas Schou, "The Decline of the Democratic Party in Iowa, 1916-1920" (M.A. thesis, University of Iowa, 1960), 112, 135-44, 251-79, 302-7. Note that the 1921-22 Official Register did not provide detailed countylevel voting results. Only state and county totals are available for the 1920 elections. Wapello County and Ottumwa's large return for Democrats in the 1924 and 1930 U.S. Senate races probably was at least in part owing to the fact that Dan Steck was a native Ottumwan. On the 1926 senate race in Iowa, see George William McDaniel, Smith Wildman Brookhart: Iowa's Renegade Republican (Ames, IA, 1995), 196-98, 270-73. The New Dealer label for Brookhart's politics is by Claude Pepper and quoted in McDaniel, Smith Wildman Brookhart, 273. On thirdparty support in Ottumwa and Wapello County, see Ottumwa Daily Democrat, 8/12/1901; Ottumwa Morning Democrat, 9/6/1903; James Weinstein, The Decline of Socialism in America, 1912-1925 (New Brunswick, NJ, 1984), 44, 96, 116-18; David P. Thelen, Robert M. LaFollette and the Insurgent Spirit (Boston, 1976), 190. On the general lack of voter support for populists in Iowa, see Ostler, Prairie Populism, esp. 154-74. On socialism in Iowa, see William H. Cumberland, "The Red Flag Comes to Iowa," Annals of Iowa 39 (1968), 453-54.

7. State of Iowa, Official Registers, 1937-38 through 1973-74; and Cox, State and National Voting. 
late 1930s and early 1940s made the larger political context for workers' local workplace efforts more important. During the 1940s and 1950s, workers' forays into local politics mirrored the struggles within the plant. Workers running for local and state political offices often contested management representatives from the Morrell plant. As a consequence, while Local 1 struggled to gain union shop and dues check-off agreements in the late 1930s and early 1940s, the local also aggressively expanded its presence in Ottumwa's politics and within Iowa's CIO movement.

Over the course of the 1950s, however, as the militants among Local 1's leadership lost favor among the new workers entering the plant, they also failed to capture support in community political contests. The 1953 city elections saw the last attempt by Local 1 militants to contest for city council positions. During the same period, however, several members of the new generation of Local 1 officials, including Jack McCoy and David Hart, along with politically active members of the UAW local organized at the city's growing John Deere plant, especially Jacob "Jake" Mincks, as well as a former Morrell worker, Herschel Loveless, would successfully contest for positions in city, state, and state labor politics. Instead of viewing local and state politics as another means of punishing management and gaining greater control in rapid fashion, as the militants tended to view politics, the new generation of labor leaders were in the fray for the long haul. They were willing to work within the political system to gain benefits for their fellow workers in a way that appeared less combative than the militants' efforts and behavior. In particular, workers who began their tenure at Morrell after World War II saw the new Local 1 leaders as less self-interested and vindictive. This perception translated into a wider appeal among other Ottumwa and Iowa voters when the new generation entered politics.

The central agency of Morrell workers' political involvement was the Ottumwa Industrial Union Council (OIUC) created in 1939 by Local 1. It quickly overshadowed the city's AFL central labor body, the Trades and Labor Assembly (TLA). During the war years, animosity between the PWOC and Amalgamated in the Morrell plant mirrored the competition between the OIUC and TLA in part because Henry Hoover, leader of the small group of Amalgamated members in the Morrell plant and infamous 
among Local 1 members for his attempted back-to-work movement during the 1939 strike, served as TLA president. In September 1941, for example, competition between the two groups flared into a fierce struggle over union affiliation of the city's truck drivers. Local 1 had urged the members of the AFL-affiliated International Brotherhood of Teamsters (IBT) truckers to join the CIO's Motor Transport Drivers and Allied Workers, led by former IBT (and IUAW) leaders Farrell Dobbs, Carl Nilson, and the Dunne brothers, Trotskyites out of Minneapolis and Duluth, Minnesota, and Frank Cronin, a Waterloo-area organizer who later became a $\mathrm{CIO}$ regional director in Nebraska. Local 1 provided picketers at grocers still working with IBT truckers. When Local 1's representatives on the OIUC failed to give unanimous support to the challenge to the IBT, Local 1's membership promptly asked for their representatives' resignations. OIUC president Jack Woodrow, secretary Orvel Champ, Donald Jones, and Harold Whitney, all Local 1 members, then threw their support behind Nilson's CIO efforts, but were nevertheless forced to step down because of pressure from Local 1's membership. Because of developments in Ottumwa, Iowa-Nebraska CIO director Ben Henry pledged to throw the weight of the state union apparatus behind a move of the truckers into the CIO. Despite this support from Local 1 and the state $\mathrm{CIO}$, the AFL won out over the CIO and signed a citywide contract to handle both motor and rail freight. Although unsuccessful, the struggle over the truckers' union affiliation demonstrated the widespread militancy within Local 1 and the local's commitment to larger union and political fights. ${ }^{8}$

8. Ottumwa Daily Courier, 9/2-5/1941, 9/8/1941, 9/12/1941, 9/18/1941, 9/22/ 1941; Regular Meeting of September 17, 1941, of Local 3, UPWA Local P-3 Records, 1939-1942 Minute Book, State Historical Society of Iowa (SHSI), Iowa City; Convention and Year Book, Iowa State Industrial Council, CIO, 1951, Iowa Federation of Labor (IFL), AFL-CIO Records, SHSI, Iowa City; Jacob "Jake" Mincks, interview with Iowa Labor History Oral Project (ILHOP), 10/18/1978 and 10/27/1978, SHSI, Iowa City; and Proceedings, Fifteenth Annual Constitutional Convention, Iowa State Industrial Union Council, CIO, 1953, IFL, SHSI. Cronin addressed the 1953 convention, held in Ottumwa, by thanking union members for the support they gave him in August 1941 when the Iowa-Nebraska State Industrial Union Council was also held in Ottumwa, and the delegates solidly supported him even though he was from the "rebel" Teamsters group. See Proceedings, pp. 113-23. On the schism between the AFL and CIO branches of the Teamsters, see Arthur A. Sloane, Hoffa (Cambridge, MA, 1991), 18-31. On Carl Nilson's IUAW roots, see Peter Rachleff, "Organizing 'Wall to Wall': The Inde- 
Both Local 1 and the OIUC supported candidates for local and state offices beginning in 1940. The experience of the 1939 MorrellOttumwa strike convinced union leaders that they needed a more supportive city and county government. In 1940, Charles Sears, president of Local 1 in 1939, ran for a seat on the Ottumwa school board. Sears's candidacy posed a test of union power against one of the incumbents running for reelection, recently retired Morrell superintendent and longtime worker enemy Ernest Manns. In the race to select members for three seats, Manns finished second and Sears came in fourth out of thirteen candidates. Interest in the elections, however, generated the highest turnout in a school board race in twenty years. In the next two months, Local 1 and the OIUC expanded on this interest by helping to boost voter registration in Wapello County before the May 1940 primaries. Their efforts added 1,625 new voters to the county rolls, an increase of more than 10 percent. That fall's elections resulted in the Democrats' sweep of local and state representative slots in Wapello County, a county safely Republican since the late nineteenth century. ${ }^{9}$

The impact of this 1940 voter registration campaign is also clearly evident when the total votes from the 1940 general elections are compared to earlier results. Whereas Ottumwa's population increased by 12 percent between 1930 and 1940, the total vote cast for the president went up 15 percent between 1936 and 1940, and was up nearly 20 percent from 1932. The total number of votes cast for Roosevelt in the same periods was up 16 and 25 percent in Ottumwa. At the county level, although the population had increased by 9 percent between 1930 and 1940, total votes cast for the president in 1940 were up 13 percent over 1936 and 20 percent since 1932. Correspondingly, Roosevelt received 11 percent more votes in 1940 from Wapello County voters than in 1936 and 20 percent more than in $1932 .{ }^{10}$

In addition to entering local political contests and registering voters, Morrell-Ottumwa workers involved themselves early on

pendent Union of All Workers, 1933-1937," in “We Are All Leaders': The Alternative Unionism of the Early 1930s, ed. Staughton Lynd (Urbana, IL, 1996), 57-58, 65-66.

9. Ottumwa Daily Courier, 2/28/1940, 3/12/1940, 5/24/1940, and 11/6/1940.

10. U.S. Bureau of the Census, Census of Population: 1950, vol. 1, Number of Inhabitants (Washington, DC, 1952); State of Iowa, Official Registers, 1933-34 through 1941-42. 
in a campaign to retain the structure of city government. Local 1 activists saw the city's commission form of government as potentially responsive to working people if labor union members or other union allies could be placed in office. Ottumwa's mayor as well as its streets and public improvements and public safety commissioners each received a salary that allowed them to hold office without needing an additional source of income. This fact also potentially held promise for attracting a working person to run for office. Yet almost as soon as Morrell workers launched themselves into city politics, middle-class groups mobilized to oppose their efforts. Beginning in early 1941, a middle classdominated Citizens Committee for the Council-Manager Plan proposed that Ottumwa adopt a city-manager plan of local government whereby a salaried city manager would be hired to "administer the city's business." The city council would then consist of unpaid elected officials. Members of the Citizens Committee baldly stated that under the present conditions, namely greater labor union influence, "we cannot ELECT and KEEP men of ABILITY in office." The OIUC led the opposition to the plan, and argued that it was a blatant attempt to remove working people from participating in local political affairs. Using language that echoed workers' desire for power in workplace affairs, the opposition argued that the city-manager plan would mean "ONE-MAN AUTHORITY" and would deprive citizens of "political and personal liberty." The opposition said that Ottumwa residents were being asked to "adopt the dictator plan and have a stranger rule us!" In the union's first true political success in city affairs, the citymanager plan failed in March 1941 by a more than two-to-one vote in the city as a whole and by much wider margins in the working-class precincts. In 1944, however, after racketeering charges resulted in the dismissal of the city's safety commissioner and nearly ended the mayor's tenure, middle-class residents once again attempted to secure passage of the city-manager plan. The Fosters [owners of the Morrell plant] were open proponents of the plan this time around. Once again because of Local 1's and the OIUC's efforts, it fell to defeat by an almost two-to-one margin. ${ }^{11}$

11. Ottumwa Daily Courier, 3/7/1941, 3/11-12/1941, 3/17/1941, 3/19/1941, 4/8/1944, 5/5/1944, 5/9/1944, 5/22/1944, 5/24/1944, 5/25/1944, and 6/21/ 1944. 
Engaging themselves in local politics during the early 1940s, several leading militants from Local 1 also helped to establish and lead the state's CIO council. The Iowa-Nebraska States Industrial Union Council, CIO, established in Des Moines in April 1938, held its fourth annual constitutional convention in Ottumwa in August 1941. Robert K. Gustafason from Local 1 served as one of the vice presidents. The following year, two members of Local 1 served on the council. Thomas B. Hadden, president of Local 1 in 1941, served as the secretary-treasurer alongside President Ben Henry, and Orvel Champ was one of the vice presidents. In addition, in 1942 Joseph Clark, a member of SWOC's local at the Ottumwa Iron Works, was another vice president. In 1943, Orvel Champ, Local 1's recording secretary that year, then became the secretary-treasurer of the state council with James Provenzano, a member of USWA Local 2134 of the Ottumwa Iron Works, a member of the executive board. Morrell-Ottumwa's local constituted a strong presence in the founding and World War II years of the state $\mathrm{CIO}$ council since it was the second-largest $\mathrm{CIO}$ local in the state, behind only the UAW-organized John Deere plant in Waterloo. In 1943, after the Rath plant's workforce in Waterloo joined the PWOC-CIO, Ottumwa's Local 1 then constituted the third-largest union in the state council. Indeed, Local 1 was instrumental in providing leaders for the Rath-Waterloo organizing campaign. Lester Bishop, Wilson (Moose) Rogers, and Edward Fitzpatrick all played significant roles leading up to the union's victory there in a November 1942 certification election. A year earlier, Local 1 activists helped Ottumwa's Dain, later John Deere, employees gain their first union contract, and also helped establish the Cedar Rapids Industrial Union Council. ${ }^{12}$

12. Program, Fourth Annual Constitutional Convention, Iowa-Nebraska States Industrial Union Council, 1941, IFL, SHSI; Program, Fifth Annual Constitutional Convention, Iowa-Nebraska States Industrial Union Council, 1942, IFL, SHSI; Yearbook, Iowa-Nebraska States Industrial Union Council, 1943, IFL, SHSI; Packinghouse Worker, 6/19/1942, 11/20/1942, and 12/25, 1942; Ottumwa Courier, 9/27/1941; Edward R. Fitzpatrick, PWOC field representative, to J. C. Lewis, PWOC national office, 6/4/1941, United Packinghouse Workers of America (UPWA) Records, folder 3, box 5, State Historical Society of Wisconsin (SHSW), Madison; Local 1 Regular Meeting of July 2, 1941, Minute Book, 1939-42, UPWA Records, Local P-3, SHSI; Local 1 to Sam Sponseller, UPWA District 3 Director, 7/8/1941, UPWA Records, folder 3, box 5, SHSW; and Fitzpatrick and Theo- 
During the World War II years, Morrell-Ottumwa workers continued to run for local political offices. In March 1944, another president of Local 1, Edward A. Filliman, failed in the city's school board elections. The following year, Filliman also lost by a huge margin to Frank Pedrick, a south side hardware merchant, in a race for city riverfront commissioner. In 1944, however, two union members won Wapello County's two seats in the state legislature. Dean Aubrey, a UAW member and John Deere employee, and Wade McReynolds, a bus driver and AFL member, captured those seats in a heavy general election turnout. Voters seemed already to have perceived Filliman's militant credentials as a political liability compared to Aubrey and McReynolds, who did not have the same reputation. As the fall election campaign approached, Ottumwa's packing workers became involved in the newly formed CIO-PAC. Given the organizational and voter registration efforts of the OIUC, Ottumwa-Morrell workers were well prepared to lead local PAC efforts. Local 1 had already formed its own PAC in November 1943, consisting of nine members including Donald Jones, Louis C. May, Virgil and Gene Bankson, and Dean Aubrey. Although the Iowa-Nebraska States Industrial Union Council did not make PAC a permanent part of its committee structure until 1946, the organization did place ten leading union members from across Iowa on its payroll to help with efforts to increase voter registration and distribute national PAC literature. Much of the CIO political action effort across Iowa in 1944 was focused on recruiting farmers into the Democratic party. Lyle Cooper, the UPWA international's research director, specifically commended Ottumwa's Local 1 in this regard as two farmers were elected as Democrats to formerly Republicandominated county offices. State CIO officials noted that the Iowa legislature also passed a few laws benefiting labor for the first time in twelve years, such as increased workmen's compensation benefits. Nevertheless, though the packing community's Ward One gave Roosevelt 69 percent of its vote, up from 61 percent in

dore M. Covey to Lewis J. Clark, PWOC vice president, 5/26/1942, UPWA Records, folder 3, box 5, SHSW. Fitzpatrick and Covey's report to Clark noted that "there is a very close relationship between the Morrell plant in Ottumwa and the Rath plant here [in Waterloo]. There are many Ottumwa workers here and it is thought by many that Morrell has a large financial interest in Rath." 
1940, across Ottumwa and Wapello County as a whole votes for the Democrats remained at the same levels as in 1940. Roosevelt received 58 percent from Ottumwa voters and 57 percent from voters in Wapello County. ${ }^{13}$

Nevertheless, at the local political level Democrats already dominated Wapello County's politics by World War II. Except for the period between 1906 and 1912, when the majority of elected county officials were Democrats, Wapello County's elected offices had long been held by Republicans. Beginning in 1932, however, Democrats would prevail in Wapello County elected offices through the end of the 1960s. The only year in which Republicans came close to a majority in the county was in 1942, when there were six Democrats and five Republicans. This dominance would continue long after World War II. From 1956 to 1968, in fact, there were only a total of five Republicans elected for ninety positions in the county. ${ }^{14}$

Through all of its political and welfare efforts by the end of World War II, Local 1 had made significant strides in creating loyalties to union and $\mathrm{CIO}$ political goals among a large segment of Ottumwa's working-class residents. As the largest single organization in Ottumwa during the war years, Local 1 became enmeshed in the city's welfare and wartime institutional support network. In 1943, Orvel Champ led the OIUC's War Manpower Commission and Local 1 was the second-largest donor, behind

13. The 1944 general election turnout was second only to that for the 1940 general elections. Ottumwa Daily Courier, 11/8/1944, 3/10/1945, and 3/27/1945; Packinghouse Worker, 3/30/1945; State of Iowa, Official Register, 1941-1942 (Des Moines, 1941); State of Iowa, Official Register, 1945-1946 (Des Moines, 1945); the Bulletin, 11/15/1943, folder 2, box 314, UPWA Records, SHSW; Proceedings, Eighth Annual Constitutional Convention of Iowa-Nebraska States Industrial Union Council, CIO, 1946, p. 214, IFL, SHSI; and Officer's Report to the Delegates, Resolutions and Reports of Committee's [sic], Iowa-Nebraska States Industial Union Council, Eighth Annual Convention, 1946, IFL, SHSI. J. David Greenstone notes that "the 1944 campaign . . . marked organized labor's emergence as a major national campaign organization." See Labor in American Politics (New York, 1969), 51. Nevertheless, Robert Zieger notes that "the PAC effort had fallen far short of the ambitions of CIO leaders" with Democratic margins no higher in many places with heavy PAC efforts than in those without. See Zieger, The CIO, 1935-1955 (Chapel Hill, 1995), 187. On PAC's formation and 1944 election efforts, also see James Caldwell Foster, The Union Politic: The CIO Political Action Committee (Columbia, MO, 1975), 2-45.

14. State of Iowa, Official Registers, 1933-34 through 1969-70. 
Morrell, to the National War Fund and Red Cross financial campaigns. Local 1 raised \$12,000 in 1943, over 15 percent of Ottumwa's entire goal. In 1944, Dean Aubrey served on the board of directors of Wapello County's Red Cross. Local 1 and Morrell together accounted for more than 20 percent of the Red Cross's quota for the county. ${ }^{15}$

At both the state and local level, however, the involvement of Local 1's militants in political efforts often created more controversy and turbulence than success. At the state level immediately following World War II, Local 1 militants were entrenched in positions of power on the Iowa-Nebraska States Industrial Union Council. In 1946, Orvel Champ was the group's secretary, Donald Jones was the chair of the Legislative Committee, and Edward Filliman was secretary of the Resolutions Committee. With twenty-five votes in the council, the third largest bloc-behind Waterloo's UPWA Local 46 from Rath and UAW Local 838 from John Deere - Local 1's delegates supported the council's establishment of a permanent PAC. Yet Edward Filliman in particular was adamantly opposed to increasing the per-capita tax from four to five cents to help support PAC activities. Filliman had emerged as Local 1's leading militant during World War II, and as the local's chief steward from 1945 to 1948, had masterminded many of the local's worker control efforts against Morrell's speedup campaigns. He attempted to assert the same sort of control over the state's CIO council. Instrumental in leading the separation of the Iowa-Nebraska States Council into two separate councils in 1947, he accepted Orvel Champ's nomination to be the first president of the independent Iowa CIO council and won the election. ${ }^{16}$

15. Packinghouse Worker, 6/25/1943, 11/12/1943, 3/31/1944, 4/14/1944, and 1/19/1945; and Yearbook, Iowa-Nebraska States Industrial Union Council, CIO, 1943, p. 29, IFL, SHSI. Particularly useful for understanding the CIO's creation of worker loyalties to union goals in a larger political and cultural sense by the end of World War II is Elizabeth A. Fones-Wolf, Selling Free Enterprise: The Business Assault on Labor and Liberalism, 1945-60 (Urbana, IL, 1994).

16. Proceedings, Eighth Annual Constitutional Convention of Iowa-Nebraska States Industrial Union Council, CIO, 1946, pp. 12, 206-7, and 214, IFL, SHSI; Proceedings, Ninth Annual Constitutional Convention, Iowa-Nebraska Industrial Union Council, CIO, 1947, pp. 17-25, 88-135, IFL, SHSI; and Proceedings, Organizational Meeting Iowa State Industrial Union Council, CIO, 1947, pp. 118-40, IFL, SHSI. 
Filliman's tenure as the state's CIO council president was short and combative. His tenure also coincided with a period of intense factionalism within Iowa's (and the national) CIO over various issues, particularly the Progressive party's presidential campaign. Iowa's CIO left-wingers, supportive of the Progressives, were led by Charles Hobbie, head of the United Farm Equipment and Metal Workers Union (FE). At the 1948 state CIO constitutional convention, Filliman promoted the majority report against thirdparty candidates in the fall elections. Even though Hobbie had advocated support for third-party candidates, he nevertheless nominated Filliman for another term as state council president, noting that "I have worked with him over a period of time and found him to be efficient, capable and [an] honest trade union leader." But because of charges of opportunism leveled on him by state $\mathrm{CIO}$ president Ben Henry and his frustration with the present council's constitution that did not allow him to "take and formulate and carry out policy," Filliman declined the nomination. ${ }^{17}$

From 1946 through 1948, however, when Local 1's militants were significant leaders of the state $\mathrm{CIO}$ council, they strongly influenced the political efforts the group undertook in conjunction with the national CIO-PAC as well as the various regional representatives of $\mathrm{CIO}$ unions, such as UPWA, UAW, and FE. At the same time that the UPWA and FE were especially active politically in Iowa following the disastrous 1946 elections and passage in June 1947 of the Taft-Hartley Act, the state CIO council urged greater PAC activities and greater effort in terms of farmerlaborer cooperation. The state CIO council as well as UPWA, FE, and several other unions brought their members out in droves to protest a proposed "right-to-work" law for Iowa. On April 21, 1947, 25,000 unionists picketed at the state capitol in Des Moines to no avail; the law passed Iowa's rural-dominated legislature and Republican governor Robert Blue signed it into law. ${ }^{18}$

17. Proceedings, Tenth Annual Constitutional Convention, Iowa State Industrial Union Council, CIO, 1948, pp. 76-85, IFL, SHSI. On the FE, see Toni Gilpin, "Left by Themselves: History of the United Farmer Equipment and Metal Workers Union, 1938-1955" (Ph.D. diss., Yale University, 1992). On left-wingers and the 1948 presidential campaign, see Zieger, The CIO, chapter 9.

18. National Union Farmer, 6/1/1947. 
Passage of a state "right-to-work" law galvanized both the UPWA and FE into pursuing farmer-labor organizing. Union leaders felt farmers needed to be more sympathetic to the needs of labor and see their common interests. Both unions established full-time farm relations directors in 1946, and began to pursue cooperative efforts with the Iowa Farmers Union (IFU) by the end of that year. The IFU's president beginning in 1945 was Fred W. Stover, a social democrat and devotee of Henry A. Wallace. As was true of many left-liberals and their organizations during the 1940s, Stover and the IFU pushed issues such as full employment, economic planning, expanded social welfare and civil rights programs, higher farm commodity subsidies, and international cooperation with the Soviet Union. Stover's first editorial for the Iowa Union Farmer called for closer relations with labor since "[a] sympathetic understanding by farmers of labor and labor organizations is of prime importance if we are to progress as citizens in a democracy." The fact that the IFU was as committed to social democratic programs as either the UPWA or FE greatly helped labor's coalition-building efforts with farmers. ${ }^{19}$

To be sure, the social democracy of the UPWA, FE, and IFU in this period was episodic and, as David Plotke carefully points out about this theme in American liberalism in the 1930s and 1940s, should not be seen as "an autonomous political force" and "had no chance of success" in replacing the Democratic party. Moreover, Ottumwa's workers, as they demonstrated in the 1948 national elections, were not budding social democrats, even if they wanted greater shop floor power. Nevertheless, the social democratic themes and programs of the three organizations captured the imaginations and support, however fleeting, perhaps,

19. The FE's first farm relations director was Homer Ayres, a former lieutenant governor candidate in South Dakota in 1934 on the Communist-led United Farmers League ticket. See Homer Ayres, Biographical Sketch, Fred W. Stover Progressive Party Records, box 1, University of Iowa Libraries, Special Collections, Iowa City; Iowa Union Farmer, 5/11/1946; FE News, 5/8/1946; The Unionist and Public Forum, 5/23/1946; and Allan Mathews, "Agrarian Radicals: The United Farmers League of South Dakota," South Dakota History 3 (Fall (1973), 408-21. Lee Simon was the UPWA's first farm relations director. On his appointment, see Packinghouse Worker, 4/18/1947. On Fred Stover's labor union views, see Fred W. Stover, interview with Alan K. Lathrop, 2/12/1969, Fred W. Stover Progressive Party Records, Special Collections, University of Iowa Libraries, Iowa City; Iowa Union Farmer, 6/30/1945, 7/14/1945, and 8/11/1945. 
of many workers in Ottumwa and industrial cities in Iowa and the Midwest in the period. The UPWA's social democratic programs rested on a vision of labor, capital, and the state cooperating to restructure America's economy and society so that class conflict would be reduced and all Americans would prosper. The UPWA advocated national economic planning or "planned production for abundance," practiced already in Austin, Minnesota, where union members at the Hormel packing plant had won a guaranteed annual wage. The UPWA also supported pay raises, especially those advanced in the union's national strikes of 1946 and 1948, social welfare, farmer-labor cooperation, civil rights and antidiscrimination programs, and local union participation in Democratic community politics. ${ }^{20}$

Ottumwa's Local 1 quickly became one of Iowa's most active UPWA social democratic advocates, especially in regard to farmer-labor organizing. In April 1947, Lee Simon, the UPWA's farm relations director, served as a conciliator along with Local 1 representatives for a four-day Ottumwa milk strike, in which 190 dairy farmers refused to accept the price cut imposed by four area milk distributors. Building on the success of Simon's efforts, Stover, Simon, and the Reverend John Harley Telfer, pastor of the First Congregationalist Church in Ottumwa, elaborated in May on the IFU district conference theme, "Building for Peace and Abundance," by speaking to Ottumwans on "Farmer-Labor Teamwork for Peace and Abundance." Telfer, an Ottumwa resident

20. On the UPWA's post-World War II social democratic agenda, see especially Wilson J. Warren, "The Limits of Social Democratic Unionism in Midwestern Meatpacking Communities: Patterns of Internal Strife, 1948-1955," in Unionizing the Jungles: Labor and Community in the Twentieth-Century Meatpacking Industry, ed. Shelton Stromquist and Marvin Bergman (Iowa City, 1997), 128-58; Roger Horowitz, " 'This Community of our Union': Shopfloor Power and Social Unionism in the Postwar UPWA," in Unionizing the Jungles, 96-127; Horowitz, "Negro and White, Unite and Fight!": A Social History of Industrial Unionism in Meatpacking, 1930-1990 (Urbana, IL, 1997), 206-42; and Rick Halpern, Down on the Killing Floor: Black and White Workers in Chicago's Packinghouses, 1904-54 (Urbana, IL, 1997), 20145. On the social democratic programs of other $\mathrm{CIO}$ unions, see Kevin Boyle, The UAW and the Heyday of American Liberalism, 1945-1968 (Ithaca, 1995); Gilpin, "Left by Themselves"; and Ronald W. Schatz, The Electrical Workers: A History of Labor at General Electric and Westinghouse, 1923-60 (Urbana, IL, 1983). Also useful is Steve Rosswurm, ed., The CIO's Left-Led Unions (New Brunswick, NJ, 1992). For a perceptive analysis of the limitations of social democracy within the Democratic political order, see David Plotke, Building a Democratic Political Order: Reshaping American Liberalism in the 1930s and 1940s (Cambridge, 1996), esp. 174-76, 364-67. 
since July 1945, had already made a name for himself as an outspoken advocate for black civil rights. Educated at the University of Chicago, he had been director of the Milwaukee Federation Forum and Milwaukee Town Hall before moving to Ottumwa. He chaired Ottumwa's Interracial Committee and the People's Flood Prevention Committee, an organization of local farmers and laborers. Beginning in 1947, he became the UPWA District 3's radio show host. The show aired three times weekly and was described by the UPWA as one of the most widely aired labor radio shows in the country. ${ }^{21}$

Soon after the IFU conference, Local 1 formed one of the first UPWA local union farmer-labor committees. Later in the fall, Ottumwa was the site of the UPWA-IFU jointly sponsored FarmerLabor Day picnic. More than 3,000 people attended the two-day celebration at Wildwood Park on Ottumwa's south side and heard liberal and left-wing farm and labor leaders urge a "political revolt against [R]epublican legislators and congressmen." The picnic was organized by Ed Filliman and Dwight Anderson, a farmer from Agency and local IFU leader, along with a planning committee including five meatpacking workers, five employees of the Deere-owned Dain Company farm implement plant, two employees of the Ottumwa Iron Works, and one machine operator at the Hardscog Pneumatic Tool Works in Ottumwa. Local 1 militants later complained about how AFL groups were notably absent from this and other farm-labor efforts in Ottumwa during the period, but it is difficult to know just how eager they actually were to work with them, given earlier squabbles between the two groups. The FE also held joint meetings with the IFU during summer and fall 1947 at Charles City, home to a large Oliver farm implement plant, and other nearby northcentral Iowa locations. ${ }^{22}$

21. Ottumwa Daily Courier, 4/5/1947; Iowa Union Farmer, 4/19/1947, 5/17/1947; Packinghouse Worker, 4/18/1947; The Unionist and Public Forum, 8/28/1947; and First Congregationalist Church file, Ottumwa Public Library, Ottumwa.

22. Iowa Union Farmer, 9/20/1947; Ottumwa Daily Courier, 8/28/1947, 9/1-2 1947; The Unionist and Public Forum, 7/31/1947; McCoy's Ottumwa City Directory, 1947; and Proceedings, Ninth Annual Constitutional Convention, Iowa-Nebraska Industrial Union Council, CIO, 1947, pp. 262-63, IFL, SHSI. On the FE's efforts, see Wilson J. Warren, “The 'People's Century' in Iowa: Coalition-Building among Farm and Labor Organizations, 1945-1950," Annals of Iowa 49 (1988), 380-82. 
Although the state CIO council was strongly supportive of farm-labor cooperation and political efforts, inviting Fred Stover, Homer Ayres, and Lee Simon to speak on the issue at its 1946 and 1947 constitutional conventions, the state CIO, like the national CIO, was not supportive of third-party candidacies in the 1948 election. Thus, a more decidedly left-wing political impact from the joint efforts of the UPWA, FE, and IFU was limited. This is especially evident in the failure of Henry A. Wallace's presidential bid in 1948. Wallace's emphasis on programs for full employment, economic abundance, and international cooperation with the Soviet Union were attractive for many left-wingers with social democratic concerns. In late 1947 and early 1948, the FE international and Iowa's FE District 5's leadership endorsed Wallace. Some local leaders within the UPWA also lobbied on his behalf. Fred Stover bucked the National Farmers Union to endorse Wallace in the January 1948 issue of the Iowa Union Farmer. Yet in 1948, most Americans associated these planks with communism. Accordingly, such efforts were unacceptable to most farmers and laborers. Also crucial in swaying CIO members was the removal of several FE District 5 left-wingers by the state $\mathrm{CIO}$ council in August. CIO regional director Ben Henry castigated Hobbie and Stover for their support of Wallace. Despite the support and organizing efforts of the IFU, FE, and some UPWA locals on behalf of Wallace's presidential candidacy, he did not gain many votes in the November election. He only garnered 1 percent more of the total votes in north-central Iowa counties where the IFU had its largest support than his overall nationwide vote total of 2 percent. He did even worse in Ottumwa, where he received less than 2 percent of the votes cast, primarily because Local 1 leaders, such as Edward Filliman, did not encourage their membership to support him. ${ }^{23}$

23. Proceedings, Eighth Annual Constitutional Convention of Iowa-Nebraska States Industrial Council, CIO, 1946, p. 189, IFL, SHSI; Proceedings, Ninth Annual Constitutional Convention, Iowa-Nebraska Industrial Union Council, 1947, pp. 302-9, IFL, SHSI; FE News, December 1947; Iowa Union Farmer, 1/17/1948 and 10/16/1948; Des Moines Register, 11/7/1948; and Ben Henry to Fred Stover, 10/30/1948, box 1, Stover Records. On the struggle over Wallace's candidacy within the UPWA international union, see Horowitz, "Negro and White, Unite and Fight!" 198-201. On the Farmers Union and the Wallace campaign, see William C. Pratt, "The Farmers Union and the 1948 Henry Wallace Campaign," 
After 1948 left-liberal farm-labor educational efforts declined noticeably. This was owing in part to conflicts within the IFU, to conflicts between them and the state $\mathrm{CIO}$, and to the virtual absence of support for the popular front in Iowa as a whole. Another significant factor was the loosening of ties between the IFU and the UPWA. Even though UPWA District 3 leadership continued to pass resolutions supporting farm-labor work, they no longer organized farm-labor meetings and conferences. Some of this might be attributed to Lee Simon's death in September 1948. From 1948 to 1950, the UPWA devoted most of its efforts to promoting farm-labor cooperation by distributing leaflets at its booths at county fairs in the Midwest. These efforts were substantial in their own way. In the fall of 1948, for example, UPWA District 3 staffed booths at twelve county fairs in Iowa and at least two 4-H shows, and during the summer of 1949 it increased its allocations for exhibits and literature and even sponsored a group of ballad singers at over thirty local union meetings and county fairs in Iowa and Nebraska. In all, the UPWA visited more than forty fairs in 1949 and expanded its monthly literature mailings to farmers from 14,000 to 100,000 pieces between 1948 and 1949. Yet in 1949 the UPWA no longer was as active in sponsoring farm-labor meetings and conferences, unlike the FE, which merged reluctantly with another outcast CIO international, the United Electrical, Radio and Machine Workers of America (UE). Local 1's farmlabor committee also evaporated during these years. Consequently, after 1948 the FE was the only labor union willing to work in this way with the IFU. ${ }^{24}$

Criticism within the state CIO council during the early 1950s singled out several problems with mainstream CIO farmer-labor cooperative and political efforts. In 1951, Jacob “Jake" Mincks, a member of UAW Local 74 representing Ottumwa's John Deere plant, voiced several concerns as chair of the state CIO council's farm-labor committee about the episodic nature of labor's political

Annals of Iowa 49 (Summer 1988), 349-70; Bruce Field, “The Price of Dissent: The Iowa Farmers Union and the Early Cold War, 1945-1954," Annals of Iowa 55 (Winter 1996), 1-23; and idem, Harvest of Dissent: The National Farmers Union and the Early Cold War (Lawrence, KS, 1998).

24. Packinhouse Worker, 9/9/1948, 10/1/1948, 10/7/1948, 12/8/1950; The Unionist and Public Forum, 10/14/1948, 7/14/1949; and FE News, March 1949; Marianne Robinson, interview with author, 1/28/1999 (tape in author's possession). 
efforts. Mincks, though never employed at Morrell-Ottumwa or a participant in the factionalism within Local 1, emerged as the most important unionist from Deere in Ottumwa after starting work there in 1947. He immediately became involved in local union, community, and statewide political causes. Raised on a farm south of Ottumwa, he came to live in the city in 1931 after his father's death. After working at odd jobs and for the Civilian Conservation Corps, he first joined a labor union in 1938 as a Teamster, and then worked at the Ottumwa Iron Works from 1941 to 1947 and joined the local CIO steelworkers union there. Though like the militants who formed Local 1 Mincks was an early CIO supporter, unlike them he apparently never supported militant job actions. He revealed in a later interview that he took pride that Deere had only one significant strike (in 1950) during the long period that he worked there. Although clearly ambitious in his own way, he did not view politics as a forum for punishing employers. Within a year of joining the Deere ranks, Mincks was a clear leader within the UAW local there. He was also one of the UAW's local representatives on the OIUC. In October 1948, he gave a report to the local's membership on PAC efforts, and one month later initiated a motion within the local to have them go on record supporting Ben Henry's purge of the left-wingers within the state's FE. His political involvement at the local level soon carried him into prominence within the state $\mathrm{CIO}$ council. He became a consistent voice for more concerted political efforts on the part of the state CIO council. Indeed, Jack McCoy, part of the new generation of Local 1 leaders to move into state-level politics, later described Mincks as "the pusher behind the political activities of all of us [in Ottumwa]." 25

Mincks thoroughly backed the new leadership of the state $\mathrm{CIO}$ council, led since the controversial 1948 elections by president Vernon Dale and secretary-treasurer Kenneth Everhart. Dale, a member of Amalgamated Clothing Workers of America (ACWA) Local 261 in Muscatine, and Everhart, part of UAW Local 838 in

25. Mincks, ILHOP interviews, Part I and II; Regular Meeting Minutes of 10/12/ 1948 and 11/8/1948, Minute Book, 1946-49, UAW Local No. 74 Records, SHSI, Iowa City; Proceedings, Thirteenth Annual State Convention of Iowa State Industrial Union Council, CIO, 1951, pp. 175-76, IFL, SHSI; and Jack McCoy, interview with ILHOP, 5/18/1983, Part I, SHSI. 
Waterloo, were committed especially, like Mincks, to increasing the level of funding for the state CIO council's PAC efforts. This commitment never wavered from the late 1940s through the state council's merger with the state AFL council in 1956 largely because both Dale and Everhart were reelected to their offices each year by acclamation. In 1950 this fact led to an attempt initiated by Filliman to oust them by demanding a secret ballot for the election of officers. Three years earlier, Filliman, along with many other delegates from the UPWA especially, had demanded roll call votes for the election of officers so that local union constituencies could be assured that delegates voted for the candidates they had agreed on before the convention. That motion was narrowly defeated, and so was Filliman's attempt to enforce the secret ballot provision in 1950. Nevertheless, the defeat of this motion caused several local unions, including Local 1, to withdraw from the state CIO council for the next two years. Although Filliman's overt argument all along was the need for democratic process and responsiveness, his efforts also strongly suggested a personal desire for power and control. After the return of most local union delegations to the state's fold by 1953, state CIO delegates no longer were swayed by Filliman or other $\mathrm{CIO}$ militants. The twoyear absence of the most militant voices effectively muted their voice in the state $\mathrm{CIO}$ council. ${ }^{26}$

As articulated by Dale, Everhart, and Mincks, the PAC chair beginning in 1952, effective political efforts demanded more systematic voter registration, more lobbying efforts, especially at the grassroots level, and, more than anything, a greater commitment by local union members to financially support PAC. By 1950, for instance, the national CIO-PAC was working more closely with the state $\mathrm{CIO}$ council's PAC, and had committed substantial funding for selected campaigns, especially Albert Loveland's candidacy for the U.S. Senate. Morrell-Ottumwa's Local 1 spent $\$ 3,000$ of its own funds and expended considerable manpower in canvassing unsuccessfully for Loveland on behalf of PAC. The

26. Proceedings, Organizational Meeting, Iowa State Industrial Union Council, 1947, pp. 94-113, IFL, SHSI; Proceedings, Twelfth Annual Iowa State CIO, 1950, pp. 14-17, SHSI; Reports, Thirteenth Annual Convention, Iowa State IUC-CIO, 1951, pp. 19-20; Proceedings, Thirteenth Annual State Convention of Iowa State Industrial Union Council, CIO, 1951, p. 1, IFL, SHSI; and Proceedings, Fourteenth Annual Convention, Iowa State IUC-CIO, 1952, pp. 163-91, IFL, SHSI. 
CIO hoped Loveland would also appeal to family farmers because of his support for the Brannan Plan, a proposal to hike farm supports to higher, fixed levels. Despite winning 67 percent of the First Ward's vote as well as 54 percent of Ottumwa's and 53 percent of Wapello County's votes, Loveland only mustered 45 percent of the state's total tally. Some blamed his poor showing on scathing attacks on the Brannan Plan by the American Farm Bureau Federation, a larger organization representing more prosperous individual farmers and agribusiness interests. More important, because of a lack of more consistent political efforts and money overall, Democratic candidates did not do well throughout the state. This sentiment was voiced by Mincks when he noted in his farmer-labor committee report regarding U.S. House efforts, "We down in Ottumwa can carry Wapello County, but we have four counties in the district down there. How are you going to carry the others?" Another CIO delegate noted that too few county-level PAC committees had been established. In his 1952 president's report, Dale noted that "in the early days ... too few people tried to do too much. The end result [was] a lot of noise with little accomplished." On a related issue of farmerlabor political strategies, Everhart noted in 1952 that "setting up booths at State Fairs [was not] particularly conducive to good farmer-labor relations in the state of Iowa." Though thoroughly supportive of farmer-labor political efforts, he questioned the tactic of "trying to cram a farm program down the farmer's [sic] of Iowa without knowing what we are talking about." In another debate on political tactics, Everhart and Mincks stressed the need for more direct visits with local legislators. ${ }^{27}$

27. Proceedings, Thirteenth Convention, 1951, pp. 2-6, 119-23, 175-76; Proceedings, Fourteenth Convention, 1952, pp. 6-12, 70-76, 149-56. On Local 1's support for Loveland, see Edward Filliman, UPWA field representative, Weekly Report, 11/4/1950, folder 13, box 415, UPWA Records, SHSW; Morrell-Ottumwa workers' efforts on behalf of the PAC in 1950 for Loveland's campaign were most similar to those of Rockford, Illinois, Industrial Union Council's efforts as described by Fay Calkins in The CIO and the Democratic Party (Chicago, 1952), 86-111. Although unsuccessful, the OIUC was the inside force in Wapello County's Democratic party's support for Loveland in 1950. Robert Zieger's analysis of PAC's ability to more successfully generate large amounts of money for liberal candidates rather than mobilizing union voters and influencing party leaders was true of the Loveland campaign on the state level but not in Ottumwa. See Zieger, The CIO, 306-12. On the Branna Plan, see Barton J. Bernstein and Allen J. 
Again, the underlying need, according to these leaders, was greater funding for the PAC. Before the 1951 state CIO council convention, the militants, led by Filliman, had effectively blocked increases in the per-capita tax. However, without the militants' attendance at either the 1951 or 1952 conventions, Dale and Everhart were able to make the issue a key point of debate. At the 1951 convention, President Dale noted that he was sympathetic to the packinghouse workers' delegates' position against a percapita tax increase, but he stressed that the need for a two-cent increase (from five to seven cents) was pressing. The two-cent increase would be earmarked for PAC's use only. This issue was finally resolved the following year. The 1952 convention passed the two-cent per capita increase after a lengthy debate regarding the reaffiliation of the locals that owed back dues or had walked out over the per-capita issue in 1950. Initially, the Resolutions Committee passed a resolution demanding full repayment before locals were allowed back onto the state CIO council. But Fort Dodge UPWA Local 31 member and UPWA Region 3 director Russell Bull, who had helped to move Local 1 militants out of power during the 1950-1952 period, condemned the resolution for trying to "ring [sic] every last cent of blood" out of locals before letting them back in. Both Dale and Everhart reminded delegates that there was no sense in punishing delinquent locals since the PAC program needed all locals to be present and current in dues for it to function effectively. Everhart clinched support for a more moderate resolution that would give the executive board discretionary power over conditional readmittance by exclaiming that "you make councils out of people, not out of money." Ben Henry made an indirect reference to Local 1 in regard to the local union readmittance and the PAC issue by noting that "one particular local union is in an important spot in this political action program that we are going to try to promote." 28

Matusow, eds., The Truman Administration: A Documentary History, (New York, 1966), 135-39; Allen J. Matusow, Farm Policies and Politics in the Truman Years (Cambridge, MA, 1967), 196-214; Grant McConnell, The Decline of Agrarian Democracy (New York, 1977), 141-43; John L. Stover, First Majority-Last Minority: The Transformation of Rural Life in America (DeKalb, IL, 1976), 247-48; and Gilbert L. Fite, American Farmers: The New Minority (Bloomington, IN, 1981), 96-98.

28. Proceedings, Thirteenth Annual State CIO Convention, 1951, pp. 247-76; and Proceedings, Fourteenth Annual State CIO Convention, 1952, pp. 163-91. 
From 1948 to 1952, Local 1's militants also made several efforts to assert their power in community politics. But just as occurred within the state $\mathrm{CIO}$ council, these efforts all faltered. In their wake, moderate and more conciliatory Local 1 leaders emerged and experienced greater political success. Particularly in the aftermath of the tumultuous 1948 UPWA meatpacking strike, Local 1 militants focused even more attention on controlling city politics. They viewed the 1949 city council elections as crucial to the local's political power in Ottumwa in several respects. On the most basic level, Local 1 hoped to retake the offensive against the city's middle-class community that had largely been unsupportive of its strike efforts. True to their tactics at the shop floor level, Local 1 's militants wanted to mobilize union members and other bluecollar Ottumwans to defeat and punish public officials who had hindered the workers' strike efforts. As a consequence, militants even attempted to dissuade workers from supporting friends of labor, in this particular election, Herschel Loveless, because he and others were seen as not sufficiently militant. Loveless's victory would be another sign of the weakening hold the militants had in Local 1.

Early in 1949, Local 1, the OIUC, and the TLA formed the Ottumwa Policy Committee to focus working-class votes in the upcoming city elections. During the mid-March primaries, the Ottumwa Policy Committee supported David Nevin, Lester Parcell, and Patrick Harden. Each man won enough votes to be entered in the general election. Mayoral candidate Nevin and safety commissioner candidate Parcell both finished a close second. Mayor Herman Schaefer was thoroughly defeated, having won the scorn of not only working-class voters for his role in the 1948 strike, but also having alienated middle-class voters for not having controlled the situation more effectively. Streets commission candidate Patrick Harden won the primary election for this position. Local 1 then embarked on an intensive propaganda campaign during the two weeks preceding the general election. ${ }^{29}$

Local 1 supported Nevin over the other mayoral candidate, Herschel Loveless, because union leaders claimed that Loveless had not joined a union until he needed labor's political support. 
Born on a farm near Fremont, Iowa, in 1911, Loveless had moved to Ottumwa as a youngster and graduated from Ottumwa High School in 1927. He then worked for the Chicago, Milwaukee, St. Paul and Pacific Railroad through most of the Great Depression. In 1939, he joined Morrell's workforce as a turbine operator in the power plant before returning to work for the Milwaukee Railroad in 1944. On a leave of absence from the railroad, Loveless organized the street and sanitation departments and then served as the city council's emergency chief organizer during the disastrous 1947 flood in Ottumwa. It was in this capacity that he earned widespread support among Ottumwans. Nevertheless, Local 1 accused Loveless of not joining the Railway Clerk's Union until the mid-1940s when he pursued political ambitions. ${ }^{30}$

Local 1 also tried to sway working-class Ottumwans to look unfavorably on Edna Lawrence, Lester Parcell's opponent for safety commissioner in the city election. Lawrence, like Loveless, had considerable support among workers in the city. In 1948, with Local 1 support, she had won a seat in the state legislature but then resigned her office in early 1949 in hopes of winning city office. Local 1 noted that Lawrence had run unsuccessfully for local office many times before and now seemed more concerned about settling old scores than serving Ottumwans on the state level, as she had been entrusted to do. John Meagher, Harden's opponent for streets commissioner, had served in that position during the 1948 strike and had suffered consequently in the primary election. Although his role in the strike had been minor, Local 1 did not spare him, attesting that "his management of office and regard for the public [since 1947] has been very poor." Indeed, the local reminded workers of Meagher's positions as well, labeling him a "scab" for having crossed the picket line during Ottumwa's 1922 railroad strike. ${ }^{31}$

Before the general election, Local 1 reminded the packing community and other blue-collar residents to "recall just what position certain members of the City Council took in regards to the strike action at Morrells last year." Yet, just before the election,

30. On Loveless's background, see Ottumwa Daily Courier, 2/12/1949 and 5/9/ 1989; Larew, A Party Reborn, 54-56; Hahn, Urban-Rural Conflict, 79; and the Bulletin (Local 1's official newspaper), 3/24/1949, UPWA Records, box 441, SHSW.

31. The Bulletin, 3/24/1949. 
the Ottumwa Policy Committee alliance of AFL and CIO unions broke down. It is not clear which side initiated the split, but Local 1 was left alone in support of its candidates. It seems fair to speculate, however, that many Ottumwa voters, even among the city's working class, saw Local 1's decision to stick with its candidates as evidence of its combativeness. Most of the other AFL and $\mathrm{CIO}$ unions in town supported Loveless over Nevin because of Loveless's help for working-class neighborhoods damaged by the 1947 flood. Lawrence, according to other unions in town, boasted significant prolabor credentials. The other unions supported Loveless, Lawrence, and Meagher. When the votes were counted, only Harden among the Local 1 endorsed candidates emerged victorious. Demonstrating the growing divisions within Local 1, the voting results in different parts of the city suggest that many of Morrell's rank and file ignored their leaders' endorsements. The east end original packinghouse community supported Nevin for mayor while south side residents, where most of the flood damage occurred, solidly cast their votes for Loveless. Thus, despite a tremendous effort on the part of the militant leadership of Local 1 to reaffirm its power, the largest city election turnout in Ottumwa's history underscored the unraveling of this control and of unity within the local's ranks. ${ }^{32}$

After 1949, Local 1's militant leaders had little ability to convince blue-collar residents to support their candidates in local elections. Allegations of sloppy handling of local union funds also bothered voters. Ed Filliman, a UPWA international field representative after 1949, exacerbated tensions within the local by noting that the financial stability of Local 1 in 1950-1951 had been seriously compromised by its officers' predilection for everincreasing salaries and misappropriations of local union funds. Too many officers, Filliman noted, were "Do-Nothing, MoneyGrabbing individuals." Although it is difficult to know how much Filliman's charges were motivated by his sense of declining power, having lost a position in not only Local 1 but also on the state CIO council, he named the local's president in these years, Walter Van Tassel, as a particular culprit. In February 1951, Local 1's trustees, including Donald Jones, seconded Filliman's

32. The Bulletin, 3/28/1949; and Ottumwa Daily Courier, 3/28-29/1949. 
accusations by filing charges against Van Tassel for drawing pay for lost time at the same time that Morrell paid him for vacation time. To a large degree the fight within Local 1 during these years reflected a power struggle between the older militants and the newer generation of less combative union leaders. ${ }^{33}$

This power struggle created generally poor results for Local 1 in city elections during the early 1950s. In 1951, Van Tassel and Thomas Cohagan, Local 1's recording secretary in 1951 and a prominent member of the new generation of union leaders at Morrell-Ottumwa, ran for city offices and lost. Each candidate not only failed to win but could not gain the support of voters in the packinghouse workers' precincts. Herschel Loveless, however, again won the city's mayoral election soundly with the OIUC's solid support. Two years later, Herschel Loveless was the only one of five OIUC-endorsed candidates in the 1953 election who won versus those endorsed by the middle-class and professional voter-backed "Good Government Association." Van Tassel and Dean Aubrey both lost. 34

By 1953, internal factionalism within Local 1 had seriously compromised its ability to effectively run its own members or even gain working-class support for its endorsed candidates in city elections. The deleterious impact of this factionalism was starkly illustrated in that year when the "Good Government Association" revived its campaign to implement a council-manager plan of city government. Unlike the case in 1941 and 1944 when Local 1 had stood at the center of opposition to similar plans, in 1953 the local ignored the campaign until after enough petitions were collected by July to put it on the general election ballot. At Local 1's July 21 membership meeting, the rank and file decided to spend between $\$ 300$ and $\$ 500$ to fight its passage in a last-ditch effort. On July 26, the council-manager plan passed with 58 percent of voters supporting it. Although voters in the old First

33. Filliman, Weekly Reports, 1/20/1951, 1/27, 1951, 2/10/1951, and 6/23/1951, folder 13, box 415, UPWA Records, SHSW; Charles B. Simpson, Local 1 recording secretary, to Lewis J. Clark, UPWA international secretary-treasurer, 2/9/ 1951, folder 2, box 314, UPWA Records, SHSW; and Filliman to Russell Bull, UPWA District 3 director, 6/15/1951, folder 13, box 415, UPWA Records, SHSW. and Ottumwa Daily Courier, 3/14/1951, 3/27/1951, 10/17/1953, and 11/4/1953. 
Ward immediate packinghouse neighborhood rejected it by a 68 percent majority, packing workers who lived in the city's south side precincts contributed to its victory. ${ }^{35}$

Although factionalism within Local 1 contributed to the losses in community politics in 1953, Ottumwa mayor Herschel Loveless demonstrated his strong commitment to labor in the battle over the council-manager plan in that year. Jack McCoy, an employee of Morrell since 1949 and recording secretary for Local 1 in 1953, noted explicitly how Local 1 and the OIUC counted on Loveless's support:

When the fight over going to a city manager form of government developed, Herschel Loveless came down and visited with Dave Hart and I [sic]. He didn't want to turn over the city government to the Chamber of Commerce crowd. We said we'd do our job at the plant. The damn election was held on a Saturday, and we assigned our stewards to different precincts. They worked hard to try to stop it. The newspaper had been building that up for a long while, and they beat us on it, in spite of the stewards doing a good job. We must have fielded between sixty and eighty stewards that Saturday in the precincts in Ottumwa. ${ }^{36}$

\section{Transforming Iowa's Politics}

Although factional conflict within Local 1 diluted the union's political strength in Ottumwa during the late 1940s and early 1950s, the union mobilized sufficient power to transform state politics. By 1953, a new generation of Local 1 leaders, like Jack McCoy and Dave Hart, working closely with Jake Mincks, emerged and began to contribute to the next and more successful stage in this political transformation. In 1952, Mincks became Wapello County

35. Ottumwa Daily Courier, 4/29/1953, 7/27/1953, 10/21/1953, 10/31/1953, and 11/4/1953; and July 21, 1953, Membership Meeting of Local 1, Minute Book, October 1952-February 1955, Local P-1 Records, SHSI. The decline in workers' personal involvement in local politics dovetails with the findings of researchers during the same period who noted persistent support for labor union and Democratic political agendas by workers yet low levels of personal participation. See, for example, Arthur W. Kornhauser, Harold L. Sheppard, and Albert J. Mayer, When Labor Votes: A Study of Auto Workers (New York, 1956), 145; and Angus Campbell, Philip E. Converse, Warren E. Miller, and Donald E. Stokes, The American Voter (New York, 1960), 379.

36. McCoy, interview with ILHOP. This portion of McCoy's interview is reproduced in Stromquist, Solidarity and Survival, 284. 
Democratic chair and, in 1954, McCoy was selected as one of Local 1's representatives on the OIUC. That fall, along with Ottumwa AFL unionist Wade McReynolds and after borrowing over $\$ 1,000$ from the OIUC's building fund to finance his campaign, McCoy was then elected to the Iowa House of Representatives, a position he won again in 1956. Beginning in the mid-1950s, with the successful merger of the AFL and CIO at both the local level in Ottumwa and, more important, at the state level, Ottumwa's union leaders contributed centrally to the Democratic party's successes. ${ }^{37}$

The state CIO council's 1953 constitutional convention, fittingly held in Ottumwa, opened after an address by Mayor Herschel Loveless with Iowa CIO president Vernon Dale recognizing Ottumwa's key role in the state's labor movement. Dale noted that "much of the leadership and a great number of the membership of the early days of our organization [came from the city]. Ottumwa and its labor movement contributed much to the growth of the CIO in our state." Dale immediately went on to highlight how he viewed the state CIO council's political action efforts, activities in which Ottumwans Mincks, McCoy, and Hart would all play important roles. Mincks, as he had been since the year before, was chair of the PAC, McCoy was secretary of the credentials committee, and Hart, another prominent member of the new generation of leaders at Local 1, was secretary of the Rules Committee. Born in 1907 in the coal camp town of Hocking, Iowa, just west of Ottumwa, Hart had attended UMWA meetings with his father during the World War I era. He worked at odd jobs in Iowa and Chicago before the 1930s, when he moved to New York City. There, interrupted by military service during World War II, he held a variety of laboring positions. When his father died in 1947, Hart returned to Ottumwa and got a job at Morrell just after the 1948 strike. Quickly selected as a department steward, he became chief steward in 1952 in the wake of Local 1's receivership and most intense period of factionalism. ${ }^{38}$

37. Mincks, interview with ILHOP; and McCoy, interview with ILHOP, part 1. On McCoy's election to state office in 1954, also see Morrell Magazine, January 1955, 12; and Packinghouse Worker, February 1955.

38. Proceedings, Fifteenth Annual Constitutional Convention, Iowa State IUC, CIO, 1953, pp. 3-5, IFL, SHSI; and David Hart, interview with ILHOP, 4/12/ 1978, SHSI. 
In his comments on the legislative committee's reports at the 1953 convention, President Dale identified labor's most crucial political objectives. Labor unionists elected to the Iowa legislature, such as Kenneth Everhart and Jack McCoy, hammered away at fellow politicians about the need for passing new unemployment and workmen's compensation legislation and repealing the state's right-to-work law, the so-called Senate File 109. However, everything, according to Dale, hinged on counterbalancing the control that the Republican party, and its key lobbying group, the Iowa Manufacturers Association (IMA), had in the legislature. The way to neutralize this Republican dominance was through reapportionment. Although Iowa's constitution required reapportionment after each census, no legislative reapportionment had occurred since 1886. According to political scientist Charles Wiggins, two state constitutional amendments passed in 1904 and 1928 made reapportionment "virtually impossible." The result, especially in the state house since each county received equal representation, was that urban counties were vastly underrepresented. Dale proclaimed that reapportionment "is the only way that the people in Des Moines, Waterloo, Cedar Rapids, Davenport, Dubuque, Sioux City, and the various other cities of the state can have themselves represented." In his 1952 opening convention remarks Dale had also stressed the problem of disproportionate representation in the state legislature. There were too many "men from smaller community areas, farmers and people dependent upon the farm for their living [as well as] those directly representative of the antilabor groups, the big business boys and their lawyers" who constituted the legislators' membership. PAC chair Mincks emphasized how all the convention's resolutions tied into the need to get "our people into the political parties in this state of ours" and to raise funds for PAC. On the funds, Dale noted that the passage of the two-cent increase in the per capita tax, the so-called citizenship fund, had resulted in much "improved financial condition and ability to carry out needed projects in political action and legislation." 39

39. Proceedings, Fourteenth Annual Convention, Iowa State IUC-CIO, 1952, p. 8; and Proceedings, Fifteenth Annual Constitutional Convention, Iowa State IUC, CIO, 1953, pp. 2-5, 11, 96-98, 191-200. On Iowa's Republican-IMA alliance as connected to the reapportionment debate, see Hahn, Urban-Rural Conflict, 123, 
Reporting on the CIO's political efforts over the next two years, Dale noted incremental gains. Although the structure of the PAC program was revamped in 1954 with new full-time representatives appointed and training classes started, Dale exclaimed that "you should be getting damn well fed-up with the spectacle of a labor committee [in the state legislature] headed by a business man [sic] and overloaded by farmers who admittedly do not understand the labor problem." Although Democrats picked up eighteen seats in the House, and Republican governor Leo Hoegh agreed to some favorable appointments to various commissioner positions and made good on promises to provide increases in unemployment and workmen's compensation, labor otherwise "received little or nothing" from the state legislature. Moreover, by 1955 much of the state CIO council's discussion pertained to the more immediate issue of the imminent merger of the AFL and CIO. 40

To be sure, many veteran Iowa CIO unionists looked skeptically at the merger of the two unions. Many agreed with Ralph Helstein, UPWA president, that the merger was defensive; it was a strategy of effectively combating the strength of growing corporations during a period of national political conservatism while also conserving early gains. At the last state $\mathrm{CIO}$ council convention, held in Des Moines on June 26, 1956, much of the convention's debate was devoted to the upcoming merger convention, held the following two days in Des Moines. Mincks was one of the outspoken voices urging acceptance and the necessity of the merger. Indeed, Mincks was the guiding force between Ottumwa's CIO and AFL councils' merger, delayed at the request of the AFL council until after the state's merger. To allay the fears of the smaller AFL central body that its unions would have no voice in the new city labor council, Mincks negotiated a nearly equally partitioned representative council. Ottumwa was in the nearly unique position of having $\mathrm{CIO}$ unions outnumber AFL

198-209; Larew, A Party Reborn, 11-12, 31-34, 63-71, 85-87, 109, 144; and, especially, Charles W. Wiggins, "The Post World War II Legislative Reapportionment Battle in Iowa Politics," in Patterns and Perspectives in Iowa History, ed. Dorothy Schwieder (Ames, IA, 1973), 405-30.

40. Reports, Sixteenth Annual State IUC-CIO Convention, 1954, p. 11, IFL, SHSI; and Proceedings, Seventeenth Annual Constitutional Convention, Iowa CIO IUC, 1955, pp. 11, 25-32, IFL, SHSI. 
unions. The only other Iowa city where this was true was Waterloo, where a volunteer coordinating council had been active since 1950. When founded in August 1956, Ottumwa's AFL-CIO labor council had four AFL representatives and five CIO representatives, even though Local 1 and UAW Local 74 together accounted for 75 percent of the city's total labor union membership. ${ }^{41}$

In large part, the merger between the AFL and CIO in Iowa occurred as smoothly as it did because the top CIO council officials, like Dale, Everhart, and Mincks, were not militants but were moderates interested in practical political gains for laboring people. They saw the necessity of the merger primarily for political action purposes. Important, too, was the decision of the state's top AFL officials, most notably Ray Mills, the new AFLCIO president, to throw their support to the Democratic party. Mills, a lifelong Republican, publicly announced his switch to the Democratic party in 1955 after tiring of the IMA-dominated Republican positions on labor laws in the state. Republican governor Leo Hoegh had promised in his 1954 campaign to support the union shop, for instance, but was unable to sway the conservative forces in the legislature to overturn the state's right-towork law. By combining forces, AFL and $\mathrm{CIO}$ activists could certainly accomplish much more working together in the Iowa legislature than they could separately. Iowa's AFL-CIO merger in 1956 created a more politically unified labor movement at both the state and local levels. At the founding convention, the CIO was now outnumbered by AFL unions in the Iowa Federation of Labor (IFL), AFL-CIO, by 390 to 587 votes. Yet in several respects, the CIO still wielded considerable weight. For instance, both the UPWA and UAW received their own vice presidents because each had more than 10,000 members. UPWA Locals 46 and 1 as well as UAW Local 838 were the largest locals in the new IFL. By the 1957 IFL convention, Mincks, Hart, and McCoy all held prominent positions in the state labor federation. Mincks was the Credentials Committee chair, Hart was Resolutions Committee chair, and McCoy was the new Committee on Political Education

41. Stromquist, Solidarity and Survival, 264-71; Program, Eighteenth Annual Convention, Iowa State Industrial Union Council, 1956, pp. 10-24, IFL, SHSI; Mincks, interview with ILHOP; OIUC Minutes, 1955-56, UPWA Local P-1 Records, SHSI; and Proceedings, Tenth Annual Convention, IFL, AFL-CIO, 1965, p. 24, IFL, SHSI. 
(COPE) director. After the death of Russell Bull in 1959, Hart became director of UPWA District 3.42

In terms of approaches to political action, the IFL's basic strategy, as well as leading personnel, remained true to the CIO's original plan of attack. Farmer-labor cooperation, for instance, remained a key component of the IFL's approach to political mobilization. IFL leaders worked closely with a new farm group, the National Farmers Organization (NFO), for joint political benefit. Although its organizing strategies differed, for many farmers the NFO filled a void left by the decline of the Iowa Farmers Union, embroiled in communist accusations throughout the 1950s. Formed in 1955 and led by Oren Lee Stanley beginning in December 1956, the NFO focused its strategy for raising farm prices on aggressive organizing and collective bargaining. The NFO gained members who were disillusioned with the strategies of farm cooperatives and who felt leery about the future of the federal farm program. Adopted at its convention of 1958, the NFO's collective bargaining aimed at obtaining master contracts with livestock processors and farm commodity buyers on a "costplus" basis. Specifically, according to NFO historian Jon Lauck, the "NFO's plan involved Marketing Area Bargaining Committees, elected by NFO members, presenting offers to meatpackers and promising a steady flow of livestock, all in exchange for contracts for better prices." After signing up over 100,000 members, the NFO began to stage holding actions in 1959 as a first step toward gaining master contracts. One of the first holding actions took place at St. Joseph, Missouri, for an entire week. Packers there were able to break the effort, however, by trucking in livestock from outside the organized area. More successful holding actions took place in April 1961 in the Omaha, Kansas City, and St. Joseph areas, followed by further efforts in these and other areas in 1962-1964. ${ }^{43}$

42. Proceedings, First Merged Convention, Iowa Federation of Labor (IFL), AFLCIO, 1956, pp. 1-3, IFL, SHSI; Proceedings, Second Annual Convention, IFL, AFL-CIO, 1957, p. 4, IFL, SHSI; George S. May, "The Political Campaign," Palimpsest 36 (July 1955), 250; Larew, A Party Reborn, 51-52; and Hart, interview with ILHOP.

43. On the NFO's early history, see Fite, American Farmers, 158-64; Schwieder, Iowa, 286-87; and especially chapter 4, "The National Farmers' Organization and Collective Bargaining in Agriculture," in Jon Lauck, "American Agriculture 
At the local level, this new form of farm-labor cooperation was most successful in Waterloo after the formation of the Black Hawk Labor Council (BHLC), AFL-CIO, in 1956. Besides Ottumwa, Waterloo was the state's other strong CIO center where the merger with the AFL went smoothly because of several previous years of cooperation between the two unions. Unlike earlier efforts by the UPWA and the FE in the late 1940s, however, the BHLC's farmer-labor efforts resulted in greater political gains in this period because they were not tainted with left-wing activities. The NFO initially approached the BHLC because the farm group's organizers, though enthusiastic, had little actual experience with collective bargaining. As a consequence, the BHLC and NFO came to see each other as natural allies. ${ }^{44}$

The BHLC and NFO's collaboration resulted in the formation of a Farm-Labor Association in 1956. John Cooney, president of the BHLC from 1956 to 1965, described how farmer-labor organizing in Black Hawk County and surrounding areas of northeast Iowa worked:

Well, what happened, you know, the farmers would have one of their meetings and invite somebody from labor to come there and talk. Maybe they would have a hog roast, and they'd invite so many of us to come there. So finally we sat down and, well, if we can sit and talk here why can't we sit down at the table and talk business. We found out there was very little that we couldn't support that they were passing, and vice versa.

Paul Larsen, executive secretary of the BHLC from 1956 to 1965, elaborated on the origins of the Farm-Labor Association:

[The NFO] came to various elements of the labor movement wanting to know how to organize, wanting to work with and use the expertise of the labor movement. There were a number of people that were very active in the labor movement at that time that had had prior experience working with organizing farm groups too. [As a result of this collaboration], that was the first time that they came

and the Problem of Monopoly: The Political Economy of Grain Belt Farming, 1953-1980" (Ph.D. diss., University of Iowa, 1997).

44. Proceedings, Second Annual Convention, IFL, 1957, pp. 41-44. On the BHLC's farmer-labor organizing efforts, see Paul Larsen, interview with ILHOP, Cedar Falls, Iowa, 7/15/1981; Merle Thompson, interview with ILHOP, Waterloo, 7/14/1981; and John Cooney, interview with ILHOP, 7/16/1981. 
up with the slogan, "Collective bargaining in the marketplace." That was the first time that any farm organization had done really anything toward the idea of bargaining for their prices rather than going in and taking [what] was being offered. ${ }^{45}$

In places other than Black Hawk County, Iowa's farmers and urban laborers were drawn closer together politically during the middle and late 1950s by several specific concerns that ultimately bore fruit for the Democrats in several state races, most notably the governor's race in 1956. After several years of rising surpluses and declining prices, farmers balked at U.S. Secretary of Agriculture Ezra Taft Benson's proposal to combat the problem with flexible price supports. Even Iowa's Republican governor Leo Hoegh castigated Benson's proposal, which cost Hoegh the support of the Iowa Farm Bureau Federation. The Democratic candidate for governor, Herschel Loveless, benefited not only from this issue, but also two others, namely Hoegh's passage of a half-percent increase in the state sales tax and his strong support for blocking the serving of liquor by the drink. The IMA joined Loveless in criticizing the higher sales tax. Moreover, voters in Iowa's urban areas, where slightly more than one-half of the state's population now lived in 1956, endorsed liberalizing the state's alcohol laws. ${ }^{46}$

With a considerable war chest now available from the state AFL-CIO, combined with Democratic party resources and the support of farmers and anti-tax backers, Loveless carried the election, becoming only the fourth Democrat elected governor in Iowa since the Civil War. Election results confirm that Loveless won his greatest support in cities of 25,000 to 50,000 population and farm townships. The state's medium and large industrial cities were now Democratic strongholds, largely accounting for the second-stage gain that James Sundquist describes for the Democratic realignment in Iowa that peaked between 1954 and 1958. Two years later in 1958, similar issues and the same constituencies propelled Loveless to another term as governor and Democrats even took four of the state's eight U.S. congressional seats. In the state legislature, the Democrats increased their representation in

45. Cooney, interview with ILHOP; and Larson, interview with ILHOP. 46. Larew, A Party Reborn, 53-58. 
both the house and senate. For Wapello County, Mincks won a seat in the senate, which he would retain through 1966, while Dean Aubrey and Robert Conner, another UAW Local 74 member, won places in the house. Ottumwa Democrat Gene Glenn took over Mincks's seat from 1966 to 1974. In fact, from 1944 to 1972, Wapello County Democrats won twenty-one of the thirty total seats contested for the state house. ${ }^{47}$

Loveless made good on his campaign to repeal the half-cent sales tax increase, and along with increasing state social services and appointing professionals to various state commissions, he then made reapportionment the main focus of his term. In his address to the IFL convention in 1957, Loveless emphasized how urban groups, especially organized labor, must be better represented in state politics. Loveless spoke before the IFL convention every year he was in office, and consistently stressed a similar message underpinned by statistics on the shift in Iowa's population from rural to urban locations. In his 1957 address, for instance, he noted how the twenty-six less heavily populated senatorial districts contained about one-third of Iowa's population while the other twenty-four districts comprised about two-thirds of the population. Unless reapportionment occurred, establishment of union shop contracts and improvements in unemployment and workmen's compensation could not occur. Although

47. State of Iowa, Official Registers, 1945-46 to 1973-74; Larew, A Party Reborn, 58-63; Hahn, Urban-Rural Conflict, 74-85; Sundquist, Dynamics of the Party System, 257, 262; and Mincks, interview with ILHOP. Until 1964, representation in the Iowa House was by county. Beginning in 1964, some counties' representation was consolidated and several urban counties received more representation. This process continued through the 1970s. For the state senate, redistricting was also ongoing after 1964. Wapello County's rate of support for Democrats was quite comparable to that for counties outside Iowa that were much more urban and industrialized. From 1944 to 1952, Wapello County returned a rate of support for Democratic presidential candidates that was comparable to that returned by the ten strongest CIO counties in the United States: 57, 58, and 47 for Wapello County compared to an average of 59,56, and 53 percent for the ten counties. This is even more impressive when one considers that with 29 percent of its population defined as rural in 1950, Wapello County had a higher percentage of rural residents than all but one of the ten strongest $\mathrm{CIO}$ counties in the country. The ten strongest $\mathrm{CIO}$ counties, as identified by Foster in The Union Politic, were Lake and St. Joseph in Indiana; Genessee and Wayne in Michigan; Lucas, Stark, and Summit in Iowa; and Allegheny, Northhampton, and Westmoreland in Pennsylvania. See Foster, The Union Politic, appendix 1952A, 219. 
not specifically named in this speech, the Farm Bureau, especially, together with the IMA, hoped to blunt the urban shift in reapportionment as much as possible through a proposal referred to as the Shaff Plan, after Senator David O. Shaff of Clinton, that called for a state senate based on population and a house based on area. An attempt by the IFL, the League of Women Voters, the urban press, and the Democratic party to gain reapportionment by making the issue a constitutional convention referendum in 1960 narrowly failed after the IMA and Farm Bureau combined to spend nearly $\$ 2$ million to campaign against it while the IFL and League of Women Voters spent just \$100,000.48

Although 1960 was a disappointing year for Democrats in Iowa, especially for Loveless who lost his race for the U.S. Senate after spending more time campaigning for John F. Kennedy than himself, the election results indicated that cities of over 10,000 population were now solidly in the Democratic camp. Historian Harlan Hahn's findings indicate that the traditional role of farm townships in casting deciding albeit protest votes for Democrats from the 1930s to mid-1950s was still present after 1958 but less important than the strong support for Democrats in the larger cities. Jack McCoy, as the IFL's COPE director, also laid the groundwork for Democratic gains in the 1960s by establishing local-level COPE programs that were then integrated with the state's programs. ${ }^{49}$

The fruits of the IFL's political efforts can be seen in the success of Democratic governor, then U.S. senator, Harold Hughes throughout the 1960s as well as in Democratic gains in both the state and national legislature following the IFL's successful leadership in the reapportionment battle. Hughes initially attracted Herschel Loveless's attention through his work with the Iowa Better Trucking Bureau. After changing parties at Loveless's prompting, Hughes successfully ran for one of the state commerce commission seats in 1958. A direct, outspoken, and charismatic trucker turned politician, Hughes won the 1962 gubernatorial election by calling for action on the issues of reapportionment

48. Proceedings, Second Annual Convention, IFL, AFL-CIO, 1957, pp. 23-27, IFL, SHSI; Ottumwa Courier, 5/9/1989; and Larew, A Party Reborn, 59-60, 65-67.

49. Hahn, Urban-Rural Conflict, 82-84; Larew, A Party Reborn, 68-69; and Proceedings, Fourth Annual Convention, IFL, AFL-CIO, 1959, p. 69, IFL, SHSI. 
and liquor by the drink. In addition to weak stands on liquor reform, Republican governor Norman Erbe had irritated urban Democratic voters by standing by while his lieutenant governor, William Mooty, cast the deciding vote in allowing the passage of the Shaff Plan in 1961. During Hughes's first term, Iowa's liquor laws were repealed and the IFL filed suit in federal court in Des Moines in 1963, challenging the constitutionality of the Shaff Plan's reapportionment scheme. The court refused to act on the plan's constitutionality until after a statewide referendum was held on December 3, 1963. Following a statewide campaign against it by Hughes, organized labor and urban voters in general won an enormous victory when the Shaff Plan was defeated by a margin of 59 to 41 percent. The most overwhelming opposition to the plan came in the seventeen counties containing cities of more than 10,000 population. Wapello, Polk, Woodbury, Linn, and Black Hawk County voters, all home to significant numbers of union members, rejected it by over 80 percent majorities. Farm townships in nineteen predominantly rural counties, in contrast, supported the plan by a 70 percent margin. In a special session of the 1964 state legislature, a new temporary apportionment plan was passed that gave significant increases to urban areas in both the house and senate. A final, more equitable reapportionment plan, mandated by the federal district court in Des Moines, was finally implemented by the state legislature in 1969 and revised by the state supreme court in 1972.50

Having deemed reapportionment "the most important project that the Iowa labor movement had ever undertaken," IFL executive vice president Jake Mincks, McCoy's successor as IFL COPE chair, claimed without hyperbole that the Shaff Plan had been defeated because of trade union influence. Certainly labor unionist funding had been vital. Following McCoy's campaign to make COPE more effective on the local level, the 1962 IFL convention had passed an increase in the per-capita tax, bringing it up to ten cents per member per month. Mincks noted in his 1965

50. Larew, A Party Reborn, 73-87; Harold E. Hughes with Dick Schneider, The Man from Ida Grove: A Senator's Personal Story (Lincoln, VA, 1979), 75-89, 107, 122-24; Hahn, Urban-Rural Conflict, 123, 198-210; Wiggins, "The Post World War II Legislative Reapportionment Battle in Iowa Politics"; and State of Iowa, Official Register, 1965-66, 416. 
report to the IFL convention that in terms of state and national legislation much had been accomplished. Because of Democratic majorities in the state house and senate -101 of the 124 seats in the house and 35 of the 53 seats in the senate-" we were able to make gains that we hadn't been able to make in recent years." Among many improvements, Mincks listed a 25 percent increase in the disability benefits of workmen's compensation, positive changes in the unemployment compensation formula and waiting period, and passage of a Fair Employment Practices Act. A bill to legalize the union shop made it through the house but was defeated by four votes in the senate. ${ }^{51}$

In addition to these victories and helped by Democratic control of the state legislature from 1964 to 1968, the IFL and its Democratic allies pushed for and won annual salaries for legislators, encouraged more blue-collar citizens to run for office, and gained a strong workmen's compensation act, unemployment compensation, Iowa's OSHA law, and postcard registration during the late 1960s and early 1970s. Although some members among the IFL blamed Hughes for not pushing harder for the union shop bill, a criticism Hughes strongly rejected in his speech to the IFL convention the next year, in 1965 he helped to settle a UPWA strike at the new Iowa Beef Processors plant in Fort Dodge. At the 1968 IFL convention, Hughes cited some of the gains made for working people during his six years as Iowa's governor, including improvements in workmen's and unemployment compensation, industrial development, greater school aid, property tax relief, abolishment of the death penalty, improvements in state government organization and planning, increased highway patrol and traffic safety programs, and more state facilities for the mentally ill and physically handicapped. Moreover, even when the 1968

51. In 1948, only 25 of Iowa's 108 representatives in the House were Democrats. This fell to 12 in 1950 and just 3 in 1952. In 1954, however, there were 17, followed by 30 in 1956, 409 in 1958, 29 in 1960, and 17 in 1962. After a majority following the 1964 elections in the Iowa Senate, Democrats held a majority again in 1966 before tailing off but remaining competitive between 1968 and 1972. State of Iowa, Official Registers, 1945-46 to 1973-74; Proceedings, Seventh Annual Convention, IFL, AFL-CIO, 1962, pp. 4-5, 9, IFL, SHSI; Proceedings, Eighth Annual Convention, IFL, AFL-CIO, 1963, pp. 17-20, IFL, SHSI; Proceedings, Ninth Annual Convention, IFL, AFL-CIO, 1964, p. 1; IFL, SHSI; and Proceedings, Tenth Annual Convention, IFL, AFL-CIO, 1965, pp. 6-7, IFL, SHSI. 
elections swept many Iowa Democrats out of state and national legislative offices, the consolidation of the state's Democratic party organization in the late 1960s and early 1970s helped it to bounce back during the 1970s. After Hughes's election to the U.S. Senate in 1968, and establishment of a progressive record there, another progressive Democratic, John Culver, a ten-year veteran of the U.S. House, was elected in his place. Culver's former aide, Dick Clark, was elected to the other Senate seat in 1972. By the mid-1970s, Democrats were also back in control of both houses of the Iowa legislature. Although the Democrats' power has eroded since the 1970s, Iowa remains a competitive two-party state. ${ }^{52}$

By the mid-1960s, labor's political efforts had refashioned local Democratic parties in Iowa's industrial cities. Paul Larsen recalled how "[the BHLC] was very effective politically in endorsing and financially supporting candidates for the ... state legislative offices. And as a result of that, we were able to gain a great deal of influence that we had not had with members of the State Legislature from rural areas." The impact of the BHLC's political activities "started to show up in the elections of 1958 [when] we started to elect some people locally to the State Legislature for the first time. This improved in 1960 and 1962." When Black Hawk County went Democratic in 1964 for the first time since before the Civil War "folks down there thought it was the end of the world." John Cooney was even more blunt about the impact of organized labor on local Democratic politics:

Well, as far as I'm concerned, the Black Hawk Labor Council was the local Democratic party. We put a lot of money into it. We had good representation in this area. We encouraged a lot of people to get mixed into politics that had never thought of doing it, simply because, you know, they were knowledgeable people. ${ }^{53}$

Cooney also stressed that the BHLC built its Democratic coalition in Waterloo by involving itself in civil rights. Indeed, Waterloo established one of the first Fair Employment Practice

52. Proceedings, Eleventh Annual Convention, IFL, AFL-CIO, 1966, pp. 13-19, IFL, SHSI; Proceedings, Thirteenth Annual Convention, IFL, AFL-CIO, 1968, pp. 10-11, IFL, SHSI; Larew, A Party Reborn, 127-76; and Stromquist, Solidarity and Survival, 283-94.

53. Larson, interview with ILHOP; and Cooney, interview with ILHOP. See also Stromquist, Solidarity and Survival, 285. 
Commissions in the United States during this period. The BHLC actually built on the antidiscrimination and civil rights efforts of UPWA Local 46 at Waterloo's large Rath packing plant. Local 46 established its antidiscrimination program in 1950 and especially combated the segregation of African American women in the plant. The local also fought segregation in Waterloo beginning in 1953, and when the BHLC was formed, worked with the countywide labor council to do the same. Besides the establishment of the Fair Employment Practices Commission, the BHLC started the Martin Luther King Jr. Center for educating blacks of all ages. These anti-discrimination and civil rights initiatives solidified a cross-racial Democratic base in Waterloo. 54

Without organized labor's involvement, Iowa would not have become a true two-party state by the 1960s. Beginning with aggressive local union efforts during the 1940s in Ottumwa and prompted by the Iowa State Industrial Council's political efforts in the late 1940s and early 1950s, voters in Iowa's manufacturing centers steadily turned toward the Democrats. Helped by cooperative efforts with sympathetic farmers, Democrats made steady gains in state and national representation after the mid-1950s. Despite its national reputation as a conservative farm state, Ottumwa's union leaders along with the state's CIO movement prompted Iowa's belated participation in the New Deal political transition and established the state's modern Democratic foundations.

54. On UPWA Local 46's antidiscrimination and civil rights efforts, see Bruce Fehn, " 'The Only Hope We Had': United Packinghouse Workers Local 46 and the Struggle for Racial Equality in Waterloo, Iowa, 1948-1960," Annals of Iowa 54 (Summer 1995), 200-213. On the BHLC's civil rights initiatives, see Cooney, interview, ILHOP. 